\title{
Perceived Health, Depression and Psychological Well-Being in Older Adults: Physical Activity and Osteoarticular Disease
}

\author{
Olga Molinero (D), Alfonso Salguero (D) and Sara Márquez *D \\ Institute of Biomedicine (IBIOMED) and Department of Physical Education, University of León, \\ University Campus, 24071 León, Spain; olga.molinero@unileon.es (O.M.); alfonso.salguero@unileon.es (A.S.) \\ * Correspondence: sara.marquez@unileon.es; Tel.: +34-987293047
}

Citation: Molinero, O.; Salguero, A.; Márquez, S. Perceived Health,

Depression and Psychological

Well-Being in Older Adults: Physical Activity and Osteoarticular Disease. Sustainability 2021, 13, 8157. https:/ / doi.org/10.3390/su13158157

Academic Editors: Sidonio Serpa and Jürgen Beckmann

Received: 25 May 2021

Accepted: 19 July 2021

Published: 21 July 2021

Publisher's Note: MDPI stays neutral with regard to jurisdictional claims in published maps and institutional affiliations.

Copyright: (c) 2021 by the authors. Licensee MDPI, Basel, Switzerland. This article is an open access article distributed under the terms and conditions of the Creative Commons Attribution (CC BY) license (https:/ / creativecommons.org/licenses/by/ $4.0 /)$.

\begin{abstract}
Osteoarticular diseases are one of the effects of aging, and they are related to physical, psychological, and social functions. Physical activity seems to slow the start and progression of these kinds of illnesses and presents benefits for psychosocial health. The main aim of the study was to investigate the possible effect of physical activity level (Yale Physical Activity Survey) on quality of life (SF-36 Health Questionnaire), subjective psychological well-being (Psychological Well-being Scale), and depression levels (Geriatric Depression Scale), depending on osteoarticular illness. The sample consisted of 263 Spanish adults aged 65 to 98 years who had high or low physical activity (assessed by YPAS Questionnaire) and osteoarticular disease. Results show that physical activity influences the perceived quality of life, depression levels, and subjective well-being in older adults regardless of osteoarticular disease. The present study suggests the need for promoting physical exercise due to its proven positive impact on older adults' mental health, entailing a significant reduction in the risks of suffering from a variety of frequent diseases and disorders.
\end{abstract}

Keywords: osteoarticular disease; physical activity; well-being

\section{Introduction}

The aging process generates important changes in lifestyle, and it has significant repercussions for disease prevalence and the quality of life. Biologically, people begin to age from birth at different rates, and their evolution is affected by social situation, cultural environment, genetic heritage, diet, and lifestyle, with genetic factors accounting for $25 \%$ to $30 \%$ of variation across individuals, and environmental factors accounting for the rest [1].

Aging generates physiological changes in the osteoarticular system due to daily use and sequelae left by diseases and accumulated traumas throughout life [2]. Osteoarticular diseases are those that affect bones, cartilage, tendons, and/or joints-temporary or permanent-and that cause mild, moderate, or severe disability [3], with the highest prevalence in older adults [4]. These pathologies are responsible for decreasing physical activity and for increasing falls and fractures, which contributes to loss of autonomy for daily activities and increases mortality and demand for public health services [5,6]. Some studies have concluded that these kinds of diseases could be related to heart diseases and to severe physical limitations when an upper limb is affected [7,8]. Psychological and social effects are other consequences of aging, affecting mood states, anxiety, depression, and the risk of suffering neurodegenerative diseases where the physical function plays an important role in its development [9].

Physical activity has turned out to be one of the most important forms of behavioural intervention that positively influences aging processes. It prolongs life and increases independence [10]. Physical activity counteracts the loss of bone muscle mass. That helps individuals improve neuromuscular capacity, thereby avoiding the detrimental consequences of falling [11]. It develops capacities such as lessening the need for pain management [12] and improving flexibility [13] and static and dynamic balance [13,14]. 
Quality of life is a complex concept whose main characteristic is its multidimensionality. It is related to the degree of satisfaction that each one has with his or her physical situation, emotional state, family, and social and emotional life [15]. The quality of life in the elderly is closely related to the degree of functionality, defined as the person's physical, mental, and social independence [12]. Goh et al. [16] pointed out that conditions such as knee and hip osteoarthritis have a direct and negative effect on physical function and quality of life, and they pointed to physical exercise as an effective treatment therapy for these types of pathologies.

Depression in older adults frequently results in a loss of quality of life and in increased dependence [17]. The prevalence of depression varies from $0.9 \%$ to $9.4 \%$ in people who live independently, but it is even higher in other settings such as hospitals and residences for the elderly $[7,18]$. This pathology is becoming an important public health problem around the world, with a very high prevalence rate in the elderly [19]. In the field of geriatrics, depression is defined as a multidimensional disorder with multiple risk factors: individual, biological, cognitive, physical, social, and psychological $[7,20,21]$. Conventional treatments for depression include pharmacotherapy (antidepressants) and psychotherapy (individual or group) [22]. In recent years, physical exercise has proven to be a preventive factor and an adjunctive treatment with antidepressants in older people. It has been effective in reducing depressive symptoms and even as an alternative to medication [23]. Salguero et al. [18] suggested that physical activity can be effective in alleviating depressive symptoms, and recent research has demonstrated the beneficial effects of programmed physical exercise in reducing depression [24-26].

Many studies link physical activity with psychological well-being and healthy lifestyles, as well as with improved health and quality of life $[27,28]$. Currently, exercise is considered an essential tool to reduce and alleviate concerns for the elderly, while it regenerates their vitality and endows them with a higher quality of life [29], even as part of the treatment of different diseases $[13,27]$.

The main aim of the study was to investigate the possible effect of physical activity levels on quality of life, on subjective psychological well-being, and on depression levels in a sample of Spanish older adults, in which some suffer from osteoarticular illness and others do not.

\section{Materials and Methods}

\subsection{Participants}

A convenience sampling was carried out. The sample consisted of 263 adults ages 65 to 98 years $\left(\right.$ mean $\left._{\mathrm{age}}=74.99 \pm 8.19\right)$ of which 95 were men $\left(\right.$ mean $\left._{\text {age men }}=76.15 \pm 7.46\right)$ and 168 were women $\left(\right.$ mean $\left._{\text {age women }}=75.49 \pm 7.69\right)$. The participants were divided into two groups depending on the presence $(n=112)$ or absence $(n=151)$ of osteoarticular disease, based on the information obtained by applying the Sociodemographic Questionnaire. Likewise, they were classified as Higher Activity Level and Lower Activity Level based on the average of the Total Physical Activity Index (TPALI) obtained through the YPAS Questionnaire (Table 1).

Table 1. Distribution of the sample according to the presence of osteoarticular disease and physical activity level obtained through the TPALI and YPAS questionnaire.

\begin{tabular}{lcccc}
\hline \multirow{2}{*}{ Activity Level } & Groups & $\mathbf{N}$ & $\begin{array}{c}\text { Men } \\
\text { Fr (\%) }\end{array}$ & $\begin{array}{c}\text { Women } \\
\text { Fr (\%) }\end{array}$ \\
\hline \multirow{2}{*}{ Higher $(n=195)$} & Osteoarticular disease & 82 & $17(17.9)$ & $65(38.7)$ \\
& No osteoarticular disease & 113 & $49(51.6)$ & $64(38.1)$ \\
\hline \multirow{2}{*}{ Lower $(n=68)$} & Osteoarticular disease & 30 & $7(7.4)$ & $23(13.7)$ \\
& No osteoarticular disease & 38 & $22(23.1)$ & $16(9.5)$ \\
\hline & Total & 263 & $95(100)$ & $168(100)$ \\
\hline
\end{tabular}

$\mathrm{N}$ = sample; $\mathrm{Fr}$ = frequency; $\%$ = percentage. 


\subsection{Measures}

An ad-hoc Sociodemographic Questionnaire was administered to collect general information about respondents, including information about the presence of osteoarticular diseases (rheumatoid arthritis, degenerative arthritis, gout, and osteoporosis) and about habits of physical activity.

To analyse subjects' health perceptions, the Spanish version of the SF-36 Health Questionnaire was administered [30,31]. Thirty-six items assess eight dimensions or scales about quality of life related to health: Physical Function, Physical Role, Body Pain, Social Function, Emotional Role, Mental Health, Vitality, and General Health.

The Spanish version of the Geriatric Depression Scale was administered (GDS) [32-34]. It is a questionnaire composed of 30 items, designed to identify depressive symptoms in elderly.

Psychological well-being was evaluated using the Psychological Well-being Scale (EBP) [35]. It consists of 65 items that assess four dimensions, of which we only used those items that analysed Psychological Well-being, Material Well-being, and Job Well-being.

Finally, the Yale Physical Activity Survey (YPAS) [36] was administered in its Spanish version [37] in order to evaluate physical activity in older adults. It is an instrument to measure physical activity two weeks before questionnaire administration on eight indices: Vigour Index (VI), Walking Index (WI), General Movement Index (GMI), Standing Index (SI), Sitting Index (SiI), Weekly Total Time Index (TTI), Weekly Total Energy Expenditure Index (TEEI), and Total Weekly Activity Index (TPALI).

\subsection{Procedure}

Participants were recruited by contacting associations and public and private residences for the elderly in León city (Spain). Administrators, psychologists, doctors, and participants were informed about the study aims, the characteristics of the sample, the questionnaires, and the time needed to respond. Participation was voluntary and anonymous, and data collection followed procedures in accordance with the ethical standards of the University of León, World Medical Association, and the Declaration of Helsinki. At all times, the participants' right to privacy and confidentiality was guaranteed, avoiding any type of identifying data, being in possession of the informed consent of each one.

\subsection{Statistical Analysis}

A descriptive data analysis was carried out calculating the mean and standard deviation for quantitative data and frequencies and percentages for the qualitative data. In addition, a $2 \times 2$ multivariate analysis of variance (MANOVA) (Physical Activity Level $\times$ Osteoarticular disease) was performed with all the indices of perceived health, depression, psychological well-being, and physical activity. To study specific differences between different groups, a post hoc analysis was carried out using the Bonferroni procedure. The statistical significance level was defined as $p<0.05$. To estimate the magnitude of the differences between groups, power size was calculated using partial eta squared $(\eta p 2)$, and the effect size was calculated using Wilks' lambda index $(\lambda)$, where values lower than 0.06 would indicate a small effect size and values above 0.15 a large effect size [38]. Data analysis was carried out using the Statistical Package for Social Sciences IBM Software (SPSS version 26.0).

\section{Results}

Results from our analyses (Table 2) show that participants without osteoarticular diseases scored significantly higher on most scales related to quality of life, demonstrating higher levels of subjective $\left(p=0.010^{* *}\right)$ and material $\left(p=0.003^{* *}\right)$ well-being. Likewise, they had higher levels on the Vigour Index (VI) $\left(p=0.018^{*}\right)$, the Standing Index (SI) $\left(p=0.022^{*}\right)$, and the Total Weekly Activity Index (TPALI) $\left(p=0.016^{*}\right)$. The most active subjects, classified according to the TPALI, obtained significantly higher levels of physical function and mental health factors, as valuated by the SF-36, rated higher on subjective 
well-being as evaluated through the EBP scale, and measured higher globally at all levels of physical activity registered by the YPAS.

In order to explore more deeply the previous results, a MANOVA analysis was carried out for each of the different questionnaire scales (Table 3). On one hand, some differences were observed between participants. People at the higher activity level had better levels of physical function, lower body pain, better general health, greater vitality, and better mental health and subjective well-being, as well as lower scores in depression. On the other hand, the population with the lower activity level (and with osteoarticular disease) obtained the lowest values on most scales of perceived quality of life and well-being. Although this type of pathology can affect people's day-to-day life, we could see how those who were considered to be more active patients obtained better values than older adults without the pathology. They showed better results than healthy participants who were less active on indices of body pain, subjective well-being, and material well-being.

To complement these analyses, the effect size was calculated to determine the impact of the independent variables observed (disease and activity level) (Table 4). Significant effects of osteoarticular disease were detected on the quality of life ( $\lambda$ Wilks $=0.852$; $\mathrm{F}(8)=5.517, p=0.000 * * * ; \eta 2 \mathrm{p}=0.148 ; \Pi=1.000)$, depression levels $(\lambda$ Wilks $=0.922 ;$ $\left.\mathrm{F}(1)=20.034 ; p=0.000^{* * *}, \mathrm{\eta} 2 \mathrm{p}=0.072 ; \Pi=0.994\right)$, and subjective well-being $(\lambda$ Wilks $=0.961$; $\left.\mathrm{F}(3)=3.508 ; p=0.016^{*} ; \eta 2 \mathrm{p}=0.039 ; \Pi=0.778\right)$.

Moreover, the practice of physical activity also showed effects in the SF-36 Questionnaire $\left(\lambda\right.$ Wilks $\left.=0.860 ; \mathrm{F}(8)=5.188 ; p=0.000^{* * *} ; \eta 2 \mathrm{p}=0.140 ; \Pi=0.999\right)$ and in the YPAS $(\lambda$ Wilks $=0.609 ; \mathrm{F}(8)=20.351 ; p=0.000 * * * ; 2 \mathrm{p}=0.391 ; \Pi=1.000)$.

Checking the combined effect size of the variables, no effects were observed in any of the scales (Questionnaire SF-36 ( $\lambda$ Wilks $=0.994 ; \mathrm{F}(8)=0.195 ; p=0.991 ; \eta 2 \mathrm{p}=0.006$; $\Pi=0.109)$, GDS scale $(\lambda$ Wilks $=0.994 ; \mathrm{F}(2)=0.751 ; p=0.473 ; \eta 2 \mathrm{p}=0.006 ; \Pi=0.177)$, EBP scale $(\lambda$ Wilks $=0.973 ; \mathrm{F}(3)=2.343 ; p=0.074 ; \eta 2 \mathrm{p}=0.027 ; \Pi=0.584)$, and the YPAS Questionnaire $(\lambda$ Wilks $=0.971, \mathrm{~F}(8)=0.945 ; p=0.480 ; \eta 2 \mathrm{p}=0.029 ; \Pi=0.437)$. 
Table 2. Mean scores (mean $\pm \mathrm{Sd}$ ) and ANOVA analysis according to the presence of osteoarticular disease and physical activity level.

\begin{tabular}{|c|c|c|c|c|c|c|c|c|c|}
\hline Tools & Factors & $\begin{array}{c}\text { Osteoarticular } \\
\text { Disease } \\
\mathbf{M} \pm \mathbf{S d} \\
\end{array}$ & $\begin{array}{c}\text { No Osteoarticular } \\
\text { Disease } \\
\mathbf{M} \pm \mathbf{S d}\end{array}$ & Total & $p$ & $\begin{array}{c}\text { Osteoarticular } \\
\text { Disease } \\
\mathbf{M} \pm \mathbf{S d}\end{array}$ & $\begin{array}{c}\text { No Osteoarticular } \\
\text { Disease } \\
\mathbf{M} \pm \mathbf{S d}\end{array}$ & Total & $p$ \\
\hline \multirow{7}{*}{ SF-36 } & Physical Function & $68.75 \pm 24.25$ & $82.09 \pm 19.66$ & $76.41 \pm 22.67$ & $0.000^{* * *}$ & $65.51 \pm 25.07$ & $80.21 \pm 20.52$ & $76.41 \pm 22.67$ & $0.000^{* * *}$ \\
\hline & Physical Role & $79.46 \pm 37.10$ & $92.22 \pm 24.36$ & $86.79 \pm 31.03$ & $0.001^{* *}$ & $81.25 \pm 36.23$ & $88.72 \pm 28.85$ & $86.79 \pm 31.03$ & 0.087 \\
\hline & Body Pain & $60.09 \pm 23.80$ & $75.36 \pm 19.45$ & $68.86 \pm 22.67$ & $0.000^{* * *}$ & $67.35 \pm 27.78$ & $69.38 \pm 20.65$ & $68.86 \pm 22.67$ & 0.526 \\
\hline & General Health & $52.19 \pm 17.41$ & $62.58 \pm 19.59$ & $58.16 \pm 19.35$ & $0.000^{* * *}$ & $55.81 \pm 24.60$ & $58.97 \pm 17.16$ & $58.16 \pm 19.35$ & 0.246 \\
\hline & Vitality & $61.38 \pm 21.63$ & $74.04 \pm 19.32$ & $68.65 \pm 21.24$ & $0.000^{* * *}$ & $65.00 \pm 23.39$ & $69.92 \pm 20.35$ & $68.65 \pm 21.24$ & 0.100 \\
\hline & Social Function & $85.49 \pm 20.45$ & $91.80 \pm 14.72$ & $89.12 \pm 17.64$ & $0.004^{* *}$ & $89.71 \pm 18.06$ & $88.91 \pm 17.53$ & $89.12 \pm 17.64$ & 0.749 \\
\hline & Mental Health & $67.43 \pm 22.18$ & $78.25 \pm 19.42$ & $73.64 \pm 21.29$ & $0.000^{* * *}$ & $67.82 \pm 23.99$ & $75.67 \pm 19.93$ & $73.64 \pm 21.29$ & $0.009 * *$ \\
\hline GDS & Depression & $9.84 \pm 6.79$ & $6.37 \pm 5.69$ & $7.85 \pm 6.41$ & $0.000^{* * *}$ & $9.40 \pm 7.25$ & $7.31 \pm 6.01$ & $7.85 \pm 6.41$ & $0.020 *$ \\
\hline \multirow{3}{*}{ EBP } & $\begin{array}{l}\text { Subjective } \\
\text { Well-being }\end{array}$ & $106.44 \pm 18.88$ & $112.88 \pm 20.45$ & $110.14 \pm 20.02$ & $0.010^{* *}$ & $114.75 \pm 21.91$ & $108.53 \pm 19.11$ & $110.14 \pm 20.02$ & 0.027 * \\
\hline & Material Well-being & $37.84 \pm 9.43$ & $40.99 \pm 7.78$ & $39.65 \pm 8.65$ & $0.003^{* *}$ & $41.19 \pm 7.86$ & $39.11 \pm 8.87$ & $39.65 \pm 8.65$ & 0.088 \\
\hline & Job Well-being & $37.82 \pm 7.38$ & $38.46 \pm 8.32$ & $38.19 \pm 7.92$ & 0.521 & $39.56 \pm 8.48$ & $37.71 \pm 7.68$ & $38.19 \pm 7.92$ & 0.097 \\
\hline \multirow{6}{*}{ YPAS } & TTI (h/sem) & $34.10 \pm 23.60$ & $34.81 \pm 20.81$ & $34.51 \pm 21.81$ & 0.794 & $21.77 \pm 11.92$ & $38.95 \pm 22.73$ & 34.5121 .81 & $0.000^{* * *}$ \\
\hline & WI & $28.22 \pm 17.89$ & $30.09 \pm 17.75$ & $29.30 \pm 17.80$ & 0.401 & $34.59 \pm 13.13$ & $27.45 \pm 18.85$ & $29.30 \pm 17.80$ & $0.004^{* *}$ \\
\hline & GMI & $11.32 \pm 3.11$ & $11.42 \pm 3.18$ & $11.42 \pm 3.18$ & 0.671 & $10.09 \pm 2.53$ & $11.88 \pm 3.25$ & $11.42 \pm 3.18$ & $0.000^{* * *}$ \\
\hline & SI & $6.22 \pm 2.51$ & $6.94 \pm 2.50$ & $6.63 \pm 2.52$ & $0.022 *$ & $4.47 \pm 1.63$ & $7.39 \pm 2.34$ & $6.63 \pm 2.52$ & $0.000^{* * *}$ \\
\hline & SiI & $2.73 \pm 0.79$ & $2.70 \pm 1.13$ & $2.71 \pm 1.00$ & 0.809 & $3.06 \pm 0.81$ & $2.59 \pm 1.03$ & $2.71 \pm 1.00$ & $0.001^{* *}$ \\
\hline & TPALI & $72.87 \pm 32.61$ & $84.23 \pm 40.76$ & $79.39 \pm 37.86$ & $0.016^{*}$ & $59.07 \pm 23.92$ & $86.48 \pm 39.28$ & $79.39 \pm 37.86$ & $0.000^{* * *}$ \\
\hline
\end{tabular}

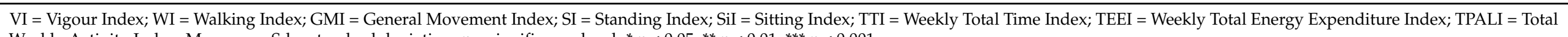
Weekly Activity Index. $\mathrm{M}=$ mean. $\mathrm{Sd}=$ standard deviation. $p=$ significance level. ${ }^{*} p<0.05,{ }^{* *} p<0.01,{ }^{* * *} p<0.001$. 
Table 3. Mean scores (mean \pm Sd) and MANOVA analysis with Bonferroni post hoc test according to the presence of osteoarticular disease and physical activity level.

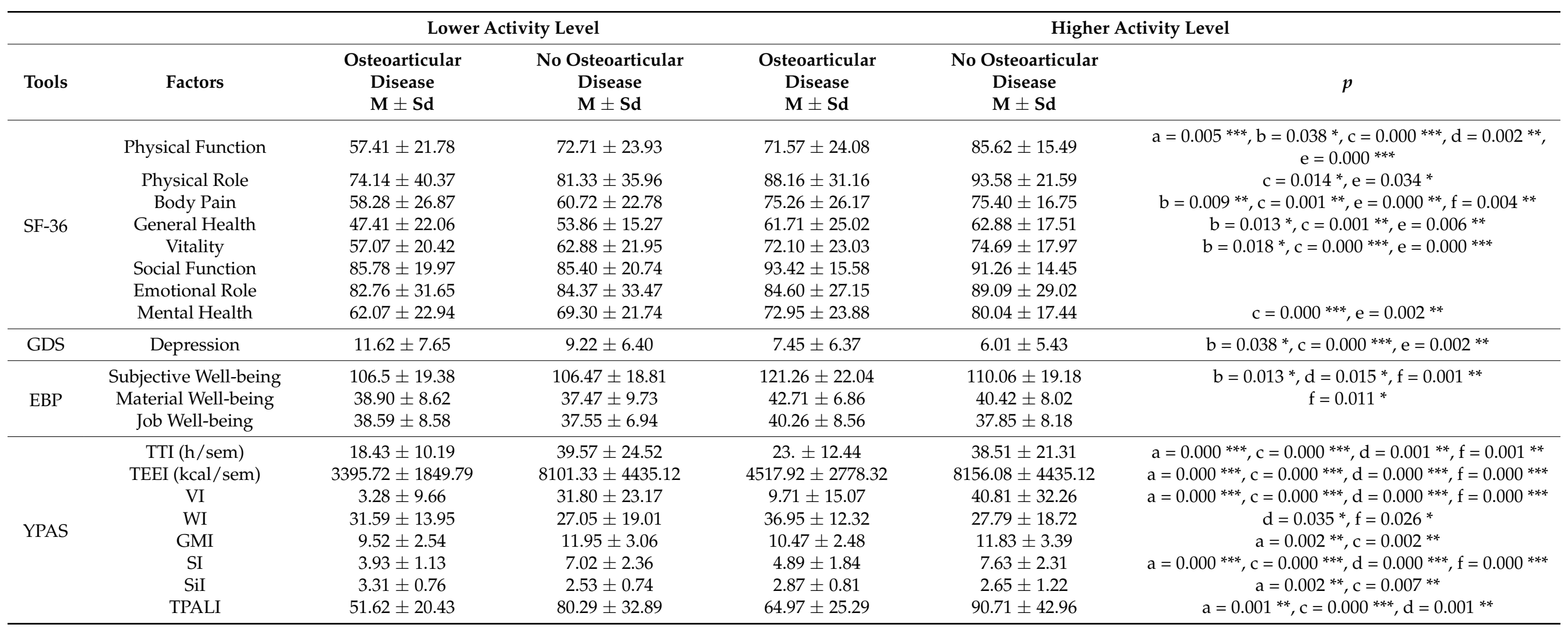

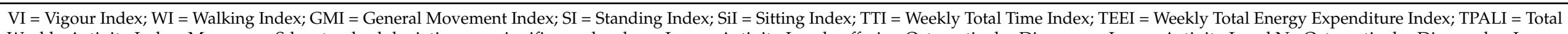

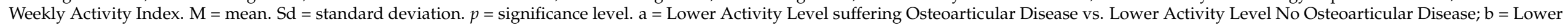

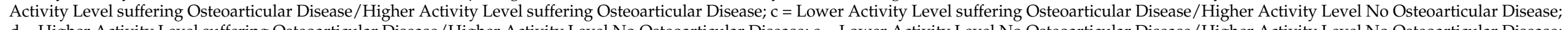

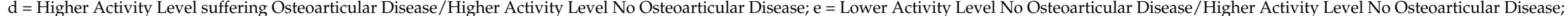
$\mathrm{f}=$ Lower Activity Level No Osteoarticular Disease/Higher Activity Level suffering Osteoarticular Disease. ${ }^{*} p<0.05,{ }^{* *} p<0.01,{ }^{* * *} p<0.001$. 
Table 4. Effect size (np2) of the variables presence of osteoarticular disease and physical activity levels.

\begin{tabular}{|c|c|c|c|c|c|c|c|c|c|c|}
\hline \multirow[b]{2}{*}{ Tools } & & \multicolumn{2}{|c|}{$\begin{array}{l}\text { Osteoarticular } \\
\text { Disease }\end{array}$} & \multicolumn{2}{|c|}{$\begin{array}{l}\text { Physical } \\
\text { Activity Level }\end{array}$} & \multicolumn{2}{|c|}{$\begin{array}{l}\text { Osteoarticular } \\
\text { Disease X } \\
\text { Physical } \\
\text { Activity }\end{array}$} & \multicolumn{3}{|c|}{ Partial Eta Squared (np2) } \\
\hline & Factors & $\mathbf{F}$ & $p$ & $\mathbf{F}$ & $p$ & $\mathbf{F}$ & $p$ & $\begin{array}{l}\text { Osteoarticular } \\
\text { Disease }\end{array}$ & $\begin{array}{c}\text { Physical } \\
\text { Activity } \\
\text { Level }\end{array}$ & $\begin{array}{c}\text { Osteoarticular } \\
\text { Disease X } \\
\text { Physical } \\
\text { Activity }\end{array}$ \\
\hline \multirow{8}{*}{ SF-36 } & Physical Function & 1.890 & 0.170 & 23.859 & $0.000^{* * *}$ & 0.022 & 0.883 & 0.007 & 0.084 & 0.000 \\
\hline & Physical Role & 1.628 & 0.203 & 2.998 & 0.085 & 0.224 & 0.636 & 0.006 & 0.011 & 0.001 \\
\hline & Body Pain & 3.885 & $0.050 *$ & 0.409 & 0.523 & 0.354 & 0.533 & 0.015 & 0.002 & 0.001 \\
\hline & General Health & 3.365 & 0.068 & 1.466 & 0.227 & 0.596 & 0.441 & 0.013 & 0.006 & 0.002 \\
\hline & Vitality & 4.080 & 0.044 * & 2.976 & 0.086 & 0.685 & 0.409 & 0.016 & 0.011 & 0.003 \\
\hline & Social Function & 1.603 & 0.207 & 0.090 & 0.764 & 0.326 & 0.568 & 0.006 & 0.000 & 0.001 \\
\hline & Emotional Role & 0.129 & 0.720 & 0.023 & 0.881 & 0.001 & 0.970 & 0.000 & 0.000 & 0.000 \\
\hline & Mental Health & 1.522 & 0.218 & 7.043 & $0.008^{* *}$ & 0.045 & 0.831 & 0.006 & 0.026 & 0.000 \\
\hline GDS & Depression & 3.382 & 0.067 & 5.827 & 0.016 * & 0.583 & 0.446 & 0.013 & 0.022 & 0.002 \\
\hline \multirow{3}{*}{$\mathrm{EBP}$} & $\begin{array}{l}\text { Subjective } \\
\text { Well-being }\end{array}$ & 6.767 & $0.010^{* *}$ & 4.141 & $0.043 *$ & 4.017 & 0.046 & 0.025 & 0.016 & 0.015 \\
\hline & $\begin{array}{c}\text { Material } \\
\text { Well-being }\end{array}$ & 0.764 & 0.383 & 3.086 & 0.080 & 0.020 & 0.887 & 0.003 & 0.012 & 0.000 \\
\hline & Job Well-being & 0.502 & 0.479 & 2.520 & 0.114 & 0.314 & 0.576 & 0.003 & 0.010 & 0.001 \\
\hline \multirow{8}{*}{ YPAS } & TTI (h/sem) & 0.947 & 0.331 & 36.062 & $0.000 * * *$ & 0.923 & 0.338 & 0.004 & 0.122 & 0.004 \\
\hline & TEEI (kcal/sem) & 0.852 & 0.357 & 46.343 & $0.000^{* * *}$ & 0.662 & 0.417 & 0.003 & 0.152 & 0.003 \\
\hline & VI & 0.117 & 0.733 & 67.970 & $0.000 * * *$ & 0.081 & 0.776 & 0.000 & 0.208 & \\
\hline & WI & 1.222 & 0.270 & 7.616 & $0.006^{* *}$ & 0.830 & 0.363 & 0.005 & 0.029 & \\
\hline & GMI & 1.408 & 0.236 & 17.892 & $0.000 * * *$ & 1.282 & 0.259 & 0.005 & 0.065 & \\
\hline & SI & 1.519 & 0.219 & 91.390 & $0.000 * * *$ & 0.413 & 0.521 & 0.006 & 0.261 & \\
\hline & SiI & 3.918 & 0.49 & 12.646 & $0.000 * * *$ & 3.978 & 0.047 & 0.015 & 0.048 & \\
\hline & TPALI & 0.842 & 0.360 & 29.194 & $0.000 * * *$ & 0.107 & 0.744 & 0.003 & 0.101 & \\
\hline
\end{tabular}

VI = Vigour Index; WI = Walking Index; GMI = General Movement Index; SI = Standing Index; SiI = Sitting Index; TTI = Weekly Total Time Index; TEEI = Weekly Total Energy Expenditure Index; TPALI = Total Weekly Activity Index. M = mean. Sd = standard deviation. $p=$ significance level. ${ }^{*} p<0.05,{ }^{* *} p<0.01,{ }^{* * *} p<0.001$.

\section{Discussion}

The pain caused by osteoarticular diseases could be the main factor for a lower perception of health, since it has been established that it is a limiting factor for performance of any daily life activity, and that could be associated with a lower quality of life [16,39]. We observed that the suffering of osteoarticular disease had a negative effect on health perception, which was supported by effect size, and significant differences for other indicators.

According to different studies, there is a direct relationship between experienced pain intensity caused by these pathologies (rheumatoid arthritis, degenerative arthritis, osteoarthritis, gout, and osteoporosis) and the degree of impairment in quality of life, both physical and mental [16,40]. Symptoms of fatigue/weakness and musculoskeletal pain, as well as depression, contribute to the deterioration of health self-perception [41]. According to Salguero et al. [18], the most limiting diseases of daily-life activities are those that would have the greatest influence on health perceptions in the elderly such as osteoarticular disease.

We observed that more active older adults, despite diagnosed disease, obtained significantly better values in quality of life than their more sedentary counterparts and sometimes even higher than the less active healthy subjects. Some studies have shown that the use of individualized exercise to improve disease symptoms generated from osteoarthritis, osteoporosis, or rheumatoid arthritis underscores the effectiveness of physical activity as a method of therapeutic intervention for reducing pain and increasing mobility, among other things $[16,42]$. Moreover, this was associated with a higher degree of functionality and perceived quality of life [39]. 
Scientific evidence indicates that low-intensity muscle-strengthening exercise is effective for improving quality of life and strength in osteoporosis patients [12]. Aerobic exercise, combined with light resistance exercise, improves or maintains joint mobility, muscle strength, aerobic capacity, bone mass, work capacity, and functional independence for people with rheumatoid arthritis while not increasing pain or inflammatory activity [43]. Recent studies conclude that the most effective physical exercise in older adults with osteoarticular diseases is called multicomponent exercise, understood as a combination of coordination, balance, aerobic, strength, and flexibility work [44,45]. Garataechea et al. [28] highlighted that the improvement of all these aspects or capacities will reinforce or improve the autonomy of the elderly. Our results show a very significant effect size on depression levels, with higher scores in people suffering osteoarticular disease, while the most active people obtained lower scores. To analyse and interpret these data correctly, we must consider that response to a chronic disease diagnosis always has complex psychological and social implications [46]. These results could be due to the frequent presence of chronic pain in older adults. Mobility reduction and even associated physical disability produced negative effects on personal independence and possible depressive disorders [47,48]. This disability and lack of independence, in addition to causing a worsening of the health of these people, are considered risk factors for falls and are associated with frailty of the elderly [48,49].

We consider that the identification of osteoarticular disease predictors, such as poor physical performance, is essential for the early identification of people at risk, as Veronese et al. [7] confirmed during a four-year study of an elderly group. Scientific literature has shown sufficient evidence to support the use of exercise in preventive treatment of depression, anxiety, and stress [7,18,24-26,50,51]. A recent study carried out during COVID-19 confinement has underscored the relationship between a reduction in physical activity levels and social distancing, worsening the mental health of the elderly and especially those who are less functional [52].

Some deterioration and loss of functionality are inherent to aging, but the evidence indicates that more physically active older people will be healthier than their more sedentary peers [28]. Regular physical activity is important to reduce the effects of osteoarticular disease. It also seems to be related to the reduction of associated pain, increased quality of life levels, and the promotion of self-efficacy and achievement [53,54]. Several studies relate the pain-perception reduction with a decrease in anxiety and depression levels and with the improvement of the individual's state of health [16,55].

The suffering from any of these pathologies conditions the assessment of subjective, material, and labour well-being, as shown by the present study. The effects of osteoarticular disease showed that people affected by this pathology and who are more physically active obtained higher well-being values. This could be the most visible part of the emotional and social disease implications, which determines the quality of life perception and well-being, and not only the physical and functional aspects of the pathology [56].

No statistical effect was found that is related to osteoarticular disease and physical activity indices, regardless of the functional implications caused by this type of disease. People who suffer from this pathology are those who perform less physical activity compared with no-disease participants as shown through the Vigour Index, Standing Index, and Weekly Total Activity Index. As we have mentioned, osteoarticular diseases are a frequent cause of pain and disability in the elderly [57]. They restrict mobility, personal care tasks, and participation in daily activities [58]; therefore, it is reasonable to think that higher levels of disease result in lower physical activity levels.

There are osteoarticular diseases not compatible with physical exercise, such as severe osteoporosis, acute connective tissue diseases, or recent fractures. Nevertheless, physical activity in this population has positive effects on balance, walking, and mobility [59]. Moreover, it can even predict and prevent falls and fractures [60,61]. This information could be useful in planning specific physical activity protocols adapted to the needs of each patient $[59,62]$. 
To summarize, we consider that physical exercise should be promoted due to its proven positive impact on older adults' mental health. It entails a significant reduction in the risks of suffering from a variety of frequent diseases and disorders [59,60,62], highlighting costs and capacity to improve self-perceptions, state mood, satisfaction with life, social interaction, and quality of life [51]. We consider that future lines of research should focus on designing and developing intervention programs adapted to different types of pathologies, emphasizing the importance of multidisciplinary work groups (doctors, psychologists, physiotherapists, nutritionists, and physical activity and sports sciences specialists).

\section{Conclusions}

The practice of physical activity influences the perceived quality of life, depression levels, and subjective well-being in older adults regardless of whether they are suffering from osteoarticular disease.

The present sample of individuals with osteoarticular pathology showed better levels in the evaluated indices than the healthy sedentary ones, which would indicate a beneficial effect of the practice of physical activity.

Therefore, the present study supports the need to develop social and health policies aimed at promoting well-being and active aging through supervised physical exercise programs adapted to the characteristics of older adults.

Author Contributions: Conceptualization, S.M., A.S., and O.M.; methodology, S.M. and O.M.; data curation, O.M.; writing—original draft preparation, A.S. and O.M.; writing-review and editing, S.M., A.S., and O.M.; visualization, O.M.; supervision, A.S. and S.M.; funding acquisition, S.M. All authors have read and agreed to the published version of the manuscript.

Funding: The León County Council (Spain) (AL24-ULE) supported this work.

Institutional Review Board Statement: Not applicable.

Informed Consent Statement: Informed consent was obtained from all subjects involved in the study.

Data Availability Statement: Data are not publicly available, though the data may be made available on request from the corresponding author.

Acknowledgments: The authors would like to thank participants for the collaboration on this study and for the commitment to facilitating the research. They would also like to thank the León County Council and the Institute of Biomedicine of the University of León.

Conflicts of Interest: The authors declare no conflict of interest.

\section{References}

1. Lozano Poveda, D. Concepción de vejez: Entre la biología y la cultura. Investigación en Enfermería. Imagen Desarrollo 2012, 13, 89-100.

2. Riedemann, P. Epidemiology of rheumatic diseases in the elderly. Medwave 2004, S4, e3228. [CrossRef]

3. López, M.; Aldave, S.; Varela, A.C. Características y Necesidades de las Personas en Situación de Dependencia; Ediciones Paraninfo: Madrid, España, 2014.

4. Pérez, R.; Iglesias, D.; Cerquera, A.M.; Martin, M.; Riquelme, A. Caracterización del dolor y las emocionales en ancianos cubanos comunitarios con dolor osteoarticular. Rev. Hosp. Psiqui. Hab. 2017, 14, 1-15.

5. Da Silva, M.A.; De Brito, K.K.G.; Matos, S.D.D.O.; Diniz, I.V.; Andrade, S.S.D.C.; De Aguiar, E.S.S.; Santana, E.M.F.; De Souza, A.P.M.A.; Meneses, L.B.D.A.; Bezerra, A.F.; et al. Resident Population in Institutions of Long Stay for Elderly. Int. Arch. Med. 2016, 9. [CrossRef]

6. Dos Santos, V.; Gobbo, L.A.; Christofaro, D.G.D.; Gomes, I.C.; Mota, J.; Gobbi, S.; Júnior, I.F.F. Osteoarticular diseases and physical performance of Brazilians over 80 years old. Cien Saude Colet. 2016, 21, 423-430. [CrossRef]

7. Veronese, N.; Stubbs, B.; Trevisan, C.; Bolzetta, F.; De Rui, M.; Solmi, M.; Sartori, L.; Musacchio, E.; Zambon, S.; Perissinotto, E.; et al. Poor Physical Performance Predicts Future Onset of Depression in Elderly People: Progetto Veneto Anziani Longitudinal Study. Phys. Ther. 2017, 97, 659-668. [CrossRef]

8. Zhang, Y.; Niu, J.; Kelly-Hayes, M.; Chaisson, C.; Aliabadi, P.; Felson, D. Prevalence of Symptomatic Hand Osteoarthritis and Its Impact on Functional Status among the Elderly: The Framingham Study. Am. J. Epidemiol. 2002, 156, 1021-1027. [CrossRef] [PubMed] 
9. Rovio, S.; Kåreholt, I.; Helkala, E.-L.; Viitanen, M.; Winblad, B.; Tuomilehto, J.; Soininen, H.; Nissinen, A.; Kivipelto, M. Leisure-time physical activity at midlife and the risk of dementia and Alzheimer's disease. Lancet Neurol. 2005, 4, 705-711. [CrossRef]

10. Sagiv, M. The role of physical activity in the elderly as primary prevention. Eur. Rev. Aging Phys. Act. 2007, 4, 59-60. [CrossRef]

11. Borst, S.E. Interventions for sarcopenia and muscle weakness in older people. Age Ageing 2004, 33, 548-555. [CrossRef] [PubMed]

12. Fragala, M.S.; Cadore, E.L.; Dorgo, S.; Izquierdo, M.; Kraemer, W.J.; Peterson, M.D.; Ryan, E.D. Resistance Training for Older Adults. J. Strength Cond. Res. 2019, 33, 2019-2052. [CrossRef]

13. Paterson, D.H.; Jones, G.R.; Rice, C.L. Ageing and physical activity: Evidence to develop exercise recommendations for older adultsThis article is part of a supplement entitled Advancing physical activity measurement and guidelines in Canada: A scientific review and evidence-based foundation for the future of Canadian physical activity guidelines co-published by Applied Physiology, Nutrition, and Metabolism and the Canadian Journal of Public Health. It may be cited as Appl. Physiol. Nutr. Metab. 32(Suppl. 2E) or as Can. J. Public Health 98(Suppl. 2). Appl. Physiol. Nutr. Metab. 2007, 32, S69-S108. [CrossRef]

14. Yümin, E.T.; Şimşek, T.T.; Sertel, M.; Öztürk, A.; Yümin, M. The effect of functional mobility and balance on health-related quality of life (HRQoL) among elderly people living at home and those living in nursing home. Arch. Gerontol. Geriatr. 2011, 52, e180-e184. [CrossRef]

15. Wanden-Berghe, C.; Martín-Rodero, H.; Rodríguez-Martín, A.; Novalbos-Ruiz, J.P.; De Victoria, E.M.; Sanz-Valero, J.; González, G.; Vila, A.; Alonso, M.V.; Marí, J.A.T.; et al. Quality of life and its determinants in Spanish university students of health sciences factors. Nutr. Hosp. 2014, 31. [CrossRef]

16. Goh, S.-L.; Persson, M.S.M.; Stocks, J.; Hou, Y.; Welton, N.; Lin, J.; Hall, M.C.; Doherty, M.; Zhang, W. Relative Efficacy of Different Exercises for Pain, Function, Performance and Quality of Life in Knee and Hip Osteoarthritis: Systematic Review and Network Meta-Analysis. Sports Med. 2019, 49, 743-761. [CrossRef] [PubMed]

17. Stella, F.; Gobbi, S.; Corazza, D.I.; Costa, J.L.R. Depressão no idoso: Diagnóstico, tratamento e benefícios da atividade física. Motriz. Motriz. J. Phys. Educ. 2002, 8, 91-98. [CrossRef]

18. Salguero, A.; Martínez-García, R.; Molinero, O.; Márquez, S. Physical activity, quality of life and symptoms of depression in community-dwelling and institutionalized older adults. Arch. Gerontol. Geriatr. 2011, 53, 152-157. [CrossRef]

19. Weyerer, S.; Eifflaender-Gorfer, S.; Köhler, L.; Jessen, F.; Maier, W.; Fuchs, A.; Pentzek, M.; Kaduszkiewicz, H.; Bachmann, C.; Angermeyer, M.C.; et al. Prevalence and risk factors for depression in non-demented primary care attenders aged 75 years and older. J. Affect. Disord. 2008, 111, 153-163. [CrossRef]

20. Laks, J.; Engelhardt, E. Peculiarities of Geriatric Psychiatry: A Focus on Aging and Depression. CNS Neurosci. Ther. 2010, 16, 374-379. [CrossRef] [PubMed]

21. Steunenberg, B.; Beekman, A.T.; Deeg, D.J.; Kerkhof, A.J. Personality predicts recurrence of late-life depression. J. Affect. Disord. 2010, 123, 164-172. [CrossRef]

22. Blumenthal, J.A.; Smith, P.J.; Hoffman, B.M. OPINION AND EVIDENCE. ACSM's Health Fit. J. 2012, 16, 14-21. [CrossRef]

23. Mura, G.; Carta, M.G. Physical Activity in Depressed Elderly. A Systematic Review. Clin. Pr. Epidemiology Ment. Health 2013, 9 , 125-135. [CrossRef]

24. Araque-Martínez, M.A.; Ruiz-Montero, P.J.; Artés-Rodríguez, E.M. Efectos de un programa de ejercicio físico multicom-ponente sobre la condición física, la autoestima, la ansiedad y la depresión de personas adultas-mayores. Retos 2021, 39, 1024-1028. [CrossRef]

25. Oliveira, L.D.S.S.C.B.D.; Souza, E.C.; Rodrigues, R.A.S.; Fett, C.A.; Piva, A.B. The effects of physical activity on anxiety, depression, and quality of life in elderly people living in the community. Trends Psychiatry Psychother. 2019, 41, 36-42. [CrossRef] [PubMed]

26. Pereira, L.G.; Fernandez, E.B.; Cruz, M.G.; Santiesteban, J.R.G. Programa de actividad física y su incidencia en la depresión y bienestar subjetivo de adultos mayores (Impact of a physical activity program on older adults' depression and subjective well-being). Retos 2017, 14-19. [CrossRef]

27. Fox, K.R.; Stathi, A.; McKenna, J.; Davis, M.G. Physical activity and mental well-being in older people participating in the Better Ageing Project. Graefe's Arch. Clin. Exp. Ophthalmol. 2007, 100, 591-602. [CrossRef]

28. Garatachea, N.; Molinero, O.; Martínez-García, R.; Jiménez-Jiménez, R.; González-Gallego, J.; Márquez, S. Feelings of well being in elderly people: Relationship to physical activity and physical function. Arch. Gerontol. Geriatr. 2009, 48, 306-312. [CrossRef]

29. Martínez, F.S.; Cocca, A.; Mohamed, K.; Ramírez, J.V. Actividad Física y sedentarismo: Repercusiones sobre la salud y calidad de vida de las personas mayores (Physical activity and sedentary lifestyle: Impact on health and quality of life of older people). Retos 2015, 126-129. [CrossRef]

30. Alonso, J.; Prieto, L.; Antó, J.M. La versión española del SF-36 health survey (cuestionario de salud SF-36): Un instrumento para la medida de los resultados clínicos. Med. Clin. 1995, 104, 771-776.

31. Ware, J.E., Jr.; Sherbourne, C.D. The MOS 36-item short-form health survey (SF-36). I. Conceptual framework and item selection. Med. Care. 1992, 30, 473-483. [CrossRef]

32. Brink, T.L.; Yesavage, J.A.; Lum, O.; Heersema, P.H.; Adey, M.; Rose, T.L. Screening Tests for Geriatric Depression. Clin. Gerontol. 1982, 1, 37-43. [CrossRef]

33. Yesavage, J.A.; Brink, T.; Rose, T.L.; Lum, O.; Huang, V.; Adey, M.; Leirer, V.O. Development and validation of a geriatric depression screening scale: A preliminary report. J. Psychiatr. Res. 1983, 17, 37-49. [CrossRef]

34. Izal, M.; Montorio, I. Adaptation of the Geriatric Depression Scale in Spain. Clin. Gerontol. 1993, 13, 83-91. [CrossRef] 
35. Sánchez-Cánovas, J. Escala de Bienestar Psicológico; TEA Ediciones, S.A.: Madrid, España, 1998.

36. Dipietro, L.; Caspersen, C.J.; Ostfeld, A.M.; Nadel, E.R. A survey for assessing physical activity among older adults. Med. Sci. Sports Exerc. 1993, 25, 628-642. [CrossRef] [PubMed]

37. De Abajo, S.; Larriba, R.; Márquez, S. Validity and reability of the YALE physical activity survey in Spanish elderly. J. Sports Med. Phys. Fit. 2001, 41, 479-485.

38. Kotrlik, J.W.; Williams, H.A. The incorporation of effect size in information technology, learning, and performance re-search Inf. Technol. Learn. Perform. J. 2003, 21, 1.

39. Araujo, I.L.A.; Castro, M.C.; Daltro, C.; Matos, M.A. Quality of Life and Functional Independence in Patients with Osteoarthritis of the Knee. Knee Surg. Relat. Res. 2016, 28, 219-224. [CrossRef]

40. Casals, M.; Samper, D. Epidemiology, prevalence and quality of life of non-malignant chronic pain. ITACA study. Rev. Soc. Esp. Dolor. 2004, 11, 260-269.

41. Molarius, A.; Janson, S. Self-rated health, chronic diseases, and symptoms among middle-aged and elderly men and women. J. Clin. Epidemiology 2002, 55, 364-370. [CrossRef]

42. Duarte, V.D.S.; Dos Santos, M.L.; Rodrigues, K.D.A.; Ramires, J.B.; Arêas, G.P.T.; Borges, G.F. Exercícios físicos e osteoartrose: Uma revisão sistemática. Fisioter. em Mov. 2013, 26, 193-202. [CrossRef]

43. Fernández-Delgado, J.O.; García, J. Efecto del ejercicio físico sobre la artritis reumatoide. Rehabilitación 2003, 37, 375-381. [CrossRef]

44. Cadore, E.; Rodríguez-Mañas, L.; Sinclair, A.; Izquierdo, M. Effects of Different Exercise Interventions on Risk of Falls, Gait Ability, and Balance in Physically Frail Older Adults: A Systematic Review. Rejuvenation Res. 2013, 16, 105-114. [CrossRef] [PubMed]

45. Valenzuela, P.L.; Castillo-García, A.; Morales, J.S.; Izquierdo, M.; Serra-Rexach, J.A.; Santos-Lozano, A.; Lucia, A. Physical Exercise in the Oldest Old. Compr. Physiol. 2019, 9, 1281-1304. [CrossRef]

46. Angarita, O.V.; Escobar, D.G. Apoyo social: Elemento clave en el afrontamiento de la enfermedad crónica. Enfermería Glob. 2009, 8. [CrossRef]

47. Matcham, F.; Rayner, L.; Steer, S.; Hotopf, M. The prevalence of depression in rheumatoid arthritis: A systematic review and meta-analysis. Rheumatology 2013, 52, 2136-2148. [CrossRef]

48. Rakhshani, T.; Ansari, M.H.; Ebrahimi, M.; Ebrahimi, M.R.; Pearson, S.K. Fear of falling and its association with anxiety and depression disorders among community-dwelling older adults. Int. J. Health Promot. Educ. 2019, 57, 303-315. [CrossRef]

49. Carneiro, J.A.; Cardoso, R.R.; Durães, M.S.; Guedes, M.C.A.; Santos, F.L.; Da Costa, F.M.; Caldeira, A.P. Frailty in the elderly: Prevalence and associated factors. Rev. Bras. Enferm. 2017, 70, 747-752. [CrossRef]

50. Alomoto, A.; Calero, S.; Vaca, M. Intervención con actividad físico-recreativa para la ansiedad y la depresión en el adulto mayor. Rev. Cubana Invest. Bioméd. 2018, 37, 47-56.

51. Fox, K.R. The influence of physical activity on mental well-being. Public Health Nutr. 1999, 2, 411-418. [CrossRef] [PubMed]

52. Esain, I.; Gil, S.; Duñabeitia, I.; Rodriguez-Larrad, A.; Bidaurrazaga-Letona, I. Effects of COVID-19 Lockdown on Physical Activity and Health-Related Quality of Life in Older Adults Who Regularly Exercise. Sustainability 2021, 13, 3771. [CrossRef]

53. Hurkmans, E.J.; Maes, S.; De Gucht, V.; Knittle, K.; Peeters, A.J.; Ronday, H.K.; Vlieland, T.V. Motivation as a determinant of physical activity in patients with rheumatoid arthritis. Arthritis Rheum. 2010, 62, 371-377. [CrossRef]

54. Knittle, K.P.; De Gucht, V.; Hurkmans, E.J.; Vlieland, T.V.; Peeters, A.J.; Ronday, H.K.; Maes, S. Effect of self-efficacy and physical activity goal achievement on arthritis pain and quality of life in patients with rheumatoid arthritis. Arthritis Rheum. 2011, 63, 1613-1619. [CrossRef]

55. Torre, F.; Martín-Corral, J.; Callejo, A.; Gómez-Vega, C.; La Torre, S.; Esteban, I.; Vallejo, R.M.; Arizaga, A. Calidad de vida relacionada con la salud y estrategias de afrontamiento ante el dolor en pacientes atendidos por una unidad de tratamiento del dolor. Rev. Soc. Esp. Dolor. 2008, 15, 83-93.

56. Carneiro, C.; Chaves, M.; Verardino, G.; Frade, A.P.; Coscarelli, P.G.; Bianchi, W.A.; Ramos-E-Silva, M.; Carneiro, S. Evaluation of fatigue and its correlation with quality of life index, anxiety symptoms, depression and activity of disease in patients with psoriatic arthritis. Clin. Cosmet. Investig. Dermatol. 2017, ume 10, 155-163. [CrossRef]

57. Arteaga, C.E.; Santacruz, J.G.; Ramírez, L.J. Evaluación del dolor musculoesquelético en el anciano. Acta Med. Colomb. AMC Org. Asoc. Columb. Med. Interna 2011, 36, 30-35. [CrossRef]

58. Falsarella, G.R.; Coimbra, I.B.; Néri, A.L.; Barcelos, C.C.; Costallat, L.T.L.; Carvalho, O.M.F.; Coimbra, A.M.V. Impact of rheumatic diseases and chronic joint symptoms on quality of life in the elderly. Arch. Gerontol. Geriatr. 2012, 54, e77-e82. [CrossRef] [PubMed]

59. Pau, M.; Leban, B.; Collu, G.; Migliaccio, G.M. Effect of light and vigorous physical activity on balance and gait of older adults. Arch. Gerontol. Geriatr. 2014, 59, 568-573. [CrossRef]

60. Lagerros, Y.T.; Hantikainen, E.; Michaëlsson, K.; Ye, W.; Adami, H.-O.; Bellocco, R. Physical activity and the risk of hip fracture in the elderly: A prospective cohort study. Eur. J. Epidemiol. 2017, 32, 983-991. [CrossRef] [PubMed]

61. Rodríguez-Berzal, E.; Durán, L.A.; Royo, I.A.; Jodar, X.A. Entrenamientos funcionales frente a específicos en la prevención de caídas en las personas mayores. Apunt. Med. l'Esport 2013, 48, 153-164. [CrossRef]

62. Altavilla, G.; D’Elia, F.; Raiola, G. A Breif Review of the Effects of Physical Activity in Subjects with Cardiovascular Disease: An Interpretative Key. Sport Mont 2018, 16, 103-106. [CrossRef] 